\title{
Radiocaesium in Cortinarius spp. mushrooms in the regions of the Reggio Emilia in Italy and Pomerania in Poland
}

\author{
Tamara Zalewska $^{1}$ - Luigi Cocchi ${ }^{2,3} \cdot$ Jerzy Falandysz $^{4}$
}

Received: 19 April 2016 / Accepted: 26 August 2016/Published online: 6 September 2016

(C) The Author(s) 2016. This article is published with open access at Springerlink.com

\begin{abstract}
Activity concentrations of ${ }^{134} \mathrm{Cs}$ and ${ }^{137} \mathrm{Cs}$ have been determined in 23 species of mushrooms of the genus Cortinarius (59 individual samples) collected from the Reggio Emilia in Italy 1992-1999 and in 4 species (16 composite samples and 413 individuals) from the Pomerania region in Poland from 1996 to 2015. Across all the Cortinarius species from the Reggio Emilia, the activity concentrations were relatively high in Cortinarius alboviolaceus, Cortinarius duracinus, Cortinarius orellanus, Cortinarius rapaceus, and Cortinarius subannulatus, in which ${ }^{137} \mathrm{Cs}$ was at 10,000 100,000 $\mathrm{Bq} \mathrm{kg}^{-1}$ dry biomass (db) in 1994. Smaller activity concentrations were found in Cortinarius bivelus, Cortinarius bulliardii, Cortinarius cotoneus, Cortinarius largus, Cortinarius lividoviolaceus, Cortinarius purpureus, Cortinarius rufo-olivaceus, Cortinarius torvus, and Cortinarius venetus with levels at $1000 \sim 6000 \mathrm{~Bq} \mathrm{~kg}^{-1}$ db from 1992 to 1994, and further in Cortinarius anserinus, Cortinarius auroturbinatus, C. largus, Cortinarius praestans, Cortinarius purpurascens, Cortinarius scaurus, Cortinarius sebaceous, Cortinarius talus, and Cortinarius variecolor with activity concentrations at $100 \sim 600 \mathrm{~Bq} \mathrm{~kg}^{-1} \mathrm{db}$ in 1994 . All
\end{abstract}

Responsible editor: Philippe Garrigues

Jerzy Falandysz

jerzy.falandysz@ug.edu.pl

1 Institute of Meteorology and Water Management-National Research Institute, Maritime Branch, Waszyngtona 42, 81-342 Gdynia, Poland

2 Gruppo Micologico e Naturalistico R, FranchiVia D, Piani, 6, I-42100 Reggio Emilia, Italy

3 Comitato Scientifico Nazionale dell' Associazione Micologica Bresadola, Via A, Volta, 46, I-38100 Trento, Italy

4 Laboratory of Environmental Chemistry \& Ecotoxicology, Gdańsk University, 63 Witta Stwosza Street, PL 80-308 Gdańsk, Poland the data were calculated for dehydrated fungal material corrected back to the exact date samples of collection. The greatest activity concentrations of ${ }^{137}$ Cs both in Italy (19921999) and Poland (1996-2010) were found in the popular Cortinarius caperatus, confirming its very high capacity of radiocaesium accumulation. Besides ${ }^{137} \mathrm{Cs}$, the isotope ${ }^{134} \mathrm{Cs}$ was detected in some species from the Reggio Emilia. An average calculated ratio of activities of ${ }^{134} \mathrm{Cs}$ to ${ }^{137} \mathrm{Cs}$ referenced to 1986 was equal to 0.38 in mushrooms from the Reggio Emilia, and this value slightly differ from that specific for Chernobyl fallout, which was 0.54 . It was calculated that ${ }^{137} \mathrm{Cs}$ originating from Chernobyl accident constituted about $68 \%$ of the total activity concentration of the isotope in Reggio Emilia in 1986, while as much as $32 \%$ of ${ }^{137} \mathrm{Cs}$ in mushrooms were from the global fallout from nuclear bomb testing.

Keywords Europe $\cdot$ Edible fungi $\cdot$ Macromycetes ·

Radioactivity $\cdot$ Radiocaesium

\section{Introduction}

The fallout from the atmospheric nuclear explosions of the twentieth century caused a global scale pollution with partly long-lived radionuclides (Bem et al. 1990; Grueter 1964; Saniewski et al. 2016). Further, two major scale nuclear power plant (NPP) accidents in Chernobyl (Ukraine, 1986) and Fukushima Daiichi (Japan, 2011) released radionuclides of various half-lives (Steinhauser 2014). The releases from the Chernobyl NPP exceeded the releases from Fukushima by one order of magnitude and caused more severe radiation related health effects (Steinhauser et al. 2014). The Chernobyl accident caused severe pollution of soils with caesium radioisotopes ${ }^{134} \mathrm{Cs}$ and ${ }^{137} \mathrm{Cs}$ in the vicinity of the nuclear facility and 
more or less in the neighboring regions in Europe (De Cort et al. 1998). The influence of the Fukushima accident on radioactivity levels in Europe was regarded as negligible (Steinhauser et al. 2013).

Mushrooms growing in the wild are specifically prone to contamination with several metallic elements (Falandysz and Borovička 2013). The nuclear weapon tests and Chernobyl accident caused a long-lasting accumulation of the radionuclides with long half-lives in soils and mushrooms. An especially high accumulation was observed for ${ }^{137} \mathrm{Cs}$ (Bakken and Olsen 1990; Baldini and Nyatemu 1990; Bulko et al. 2014; Falandysz et al. 2015a; García et al. 2015; Grodzinskaya et al. 2003, 2013; Mietelski et al. 2010). Mushrooms absorb both natural and artificial radionuclides originating from fallout and from soil substrata, and ${ }^{137} \mathrm{Cs}$ is often a major contaminant but because of species-specific accumulation some other radionuclides can also highly matter for some mushrooms and regions (Steinhauser et al. 2014; Kirchner et al. 1998).

Radiocaesium isotopes $\left({ }^{134} \mathrm{Cs}\right.$ and $\left.{ }^{137} \mathrm{Cs}\right)$ are rapidly accumulated by mushrooms from the soil contaminated with deposited fallout. This is because of a high similarity of ${ }^{134} \mathrm{Cs}$ and ${ }^{137} \mathrm{Cs}$ to stable $\mathrm{Cs}\left({ }^{133} \mathrm{Cs}\right)$ - a natural metallic trace element in mushrooms on one side and because of the very efficient mycelial network on the other side. There is also some chemical and physical analogy between the isotopes of Cs and the isotopes of potassium $(\mathrm{K})$ which is the most abundant metallic macro element present in mushrooms. Potassium concentration was found to be in the range from 34,000 to $52,000 \mathrm{mg} \mathrm{kg}^{-1}$ dry biomass ( $\mathrm{db}$; median values) in caps of edible Brown Birch Scaber Stalk Leccinum scabrum (Falandysz et al. 2007a).

The rate or efficiency of ${ }^{134} \mathrm{Cs}$ and ${ }^{137} \mathrm{Cs}$ accumulation by mushrooms can be related to status of the stable Cs in their flesh, which seems to be species specific. For example, Macrolepiota procera (Scop.) Singer is poor in total Cs with a range in caps from 0.015 to $0.043 \mathrm{mg} \mathrm{kg}^{-1} \mathrm{db}$; Amanita muscaria (L.) Lam., with from 0.063 to $0.83 \mathrm{mg} \mathrm{kg}^{-1} \mathrm{db}$; L. scabrum with from 2.7 to $7.2 \mathrm{mg} \mathrm{kg}^{-1} \mathrm{db}$ and Sarcodon imbricatus (L.) P. Karst., with $28 \pm 9 \mathrm{mg} \mathrm{kg}^{-1} \mathrm{db}$ (Kotłów et al. 2015; Falandysz et al. 2007a, b, 2008). This implies that differences in the efficiency of absorption of ${ }^{137} \mathrm{Cs}$ by fungi and accumulation in fruiting bodies follow their stable Cs status, while surplus of "easily" available ${ }^{137} \mathrm{Cs}$ in soil solution can also matter for high accumulation. In 2000, the authors Yoshida et al. reported on a good correlation between ${ }^{137} \mathrm{Cs}$ and stable ${ }^{133} \mathrm{Cs}$ contained in several species of mushrooms from Finland, Germany, and Japan (Yoshida et al. 2000).

Gypsy Cortinarius caperatus (Pers.) Fr (earlier called Rozites caperatus (Pers.) P. Karst.,) is one of many species of the genus Cortinarius (Index Fungorum 2015). This edible and tasty mushroom is popular in many regions of Europe (Falandysz 2014). Shortly after the collapse of the Chernobyl nuclear power plant, C. caperatus collected in
Europe showed high levels of radioactivity because of accumulated radiocesium (Byrne 1998; Eckl et al. 1985; Haselwandter et al. 1988; Strandberg 1994, 2004).

Both, Italy and Poland were affected by radionuclides released from the Chernobyl accident but there is a variation of the amount of deposition of radiocaesium over Europe (De Cort et al. 1998). This study aimed to update and document information on radioactivity from radiocaesium accumulated in mushrooms of some Cortinarius species and especially in C. caperatus collected in the Reggio Emilia in Italy and Pomerania in Poland. Italy and Poland are among the European countries where foraging of mushrooms is a traditional activity.

\section{Materials and methods}

The fruitbodies of the genus Cortinarius such as Cortinarius alboviolaceus (Pers.) Fr.; Cortinarius anserinus (Velen.) Rob. Henry; Cortinarius auroturbinatus (Secr.) J.F. Lange; Cortinarius bivelus (Fr.) Fr.; Cortinarius bulliardii (Pers.) Fr; Cortinarius cotoneus Fr.; Cortinarius duracinus Fr., current name Cortinarius rigens (Pers.) Fr.; Cortinarius herpeticus for which current name is Cortinarius scaurus (Fr.) Fr.; Cortinarius largus Fr.; Cortinarius lividoviolaceus (Rob. Henry ex M.M. Moser) M.M. Moser; Cortinarius melliolens Jul. Schäff., with current name Cortinarius talus Fr.; Cortinarius orellanus Fr., Cortinarius phoeniceus with current name Cortinarius purpureus (Bull.) Bidaud, Moënne-Locc. \& Reumaux; Cortinarius praestans (Cordier) Gillet; Cortinarius purpurascens Fr.; Cortinarius rapaceus Fr.; Cortinarius rufo-olivaceus (Pers.) Fr.; Cortinarius sebaceus Fr.; Cortinarius subannulatus Jul. Schäff. \& M.M. Moser; Cortinarius torvus (Fr.) Fr.; Cortinarius variecolor (Pers.) Fr., and Cortinarius venetus (Fr.) Fr. were collected from the Reggio Emilia in Italy in 1992-1994, and Cortinarius caperatus (Pers.) Fr (earlier called R. caperatus (Pers.) P. Karst) in 1992-1995 and 1999 (coordinates: 44 42' $\mathrm{N} 10^{\circ} 38^{\prime} \mathrm{E}$ ) (Table 1). The fruitbodies of $C$. caperatus were also collected from Pomerania in Poland in 1996-2010 (coordinates: $54^{\circ} 29^{\prime} \mathrm{N} 18^{\circ} 15^{\prime} \mathrm{E}$ ). Additional samples of Cortinarius species such as Cortinarius agathosmus Brandrud, H. Lindstr. \& Melot, Cortinarius olivaceofuscus Kühner, Cortinarius trivialis J.E. Lange, and Cortinarius violaceus (L.) Gray were gathered in 2013 and in 2015 in region of the village of Pomlewo (Pomerania; coordinates: $54^{\circ} 13^{\prime} 07^{\prime \prime} \mathrm{N} 18^{\circ} 21^{\prime} 28^{\prime \prime}$ E) (Table 1).

The individual cap, stipe, or a whole fruiting bodies samples were cleaned from plant and soil debris using a soft brush and a disposable plastic knife, dried, and ground (Cocchi et al. 2006; Falandysz 2014). In the case of 23 species of mushrooms from the Reggio Emilia in Italy, a single whole fruiting body was examined for each species (in total 59 individual 
Table 1 Activity concentration of ${ }^{137} \mathrm{Cs}$ in Cortinarius spp. from the Reggio Emilia in Italy and the region of the Pomerania land in Poland (Bq kg ${ }^{-1}$ dry biomass)

\begin{tabular}{|c|c|c|c|}
\hline \multirow{2}{*}{$\begin{array}{l}\text { Localization, species, date or year and sample size } \\
\text { ( } n=\text { number of fruiting bodies) }\end{array}$} & \multicolumn{3}{|c|}{ Whole fruiting bodies } \\
\hline & Caps & & Stipes \\
\hline Italy; C. alboviolaceus, $1994-09-04 / 10-04 n=2^{\#}$ & & $12,000 \pm 60(12,000-12,000)$ & \\
\hline Italy; C. anserinus, $1994-09-19 n=1^{\#}$ & & $120 \pm 10$ & \\
\hline Italy; C. auroturbinatus, $1994-11-25 n=1^{\#}$ & & $570 \pm 20$ & \\
\hline Italy; C. bivelus, 1994-09-19 $n=1^{\#}$ & & $3200 \pm 28$ & \\
\hline Italy; C. bulliardii, 1993-11-08 $n=1^{\#}$ & & $2600 \pm 30$ & \\
\hline Italy; C. caperatus, 1992-10-01/12/02/12 $n=6^{\#}$ & & $33,000 \pm 35,000(6300-100,000) 21,000^{*}$ & \\
\hline Italy; C. caperatus, $1993-08-15 / 10-02 / 15 n=3^{\#}$ & & $15,000 \pm 8000(5800-21,000) 18,000$ & \\
\hline Italy; C. caperatus, 1994-08-10/07/28/09-26/10-01/02 $n=6^{\#}$ & & $9900 \pm 5360(3300-18,800) 9900$ & \\
\hline Italy; C. caperatus, $1995-09-02 / 09 / 17 n=16^{\#}$ & & $13,000 \pm 3900(5800-16,000) 14,000$ & \\
\hline Italy; C. caperatus, $1999-07-29 / 10-24 n=2^{\#}$ & & $17,000(15,000-19,000)$ & \\
\hline Italy; C. cotoneus, $1994-09-19 / 10-12 \mathrm{n}=3^{\#}$ & & $3100 \pm 2700(340-5800) 3200$ & \\
\hline Italy; C. duracinus, $1994-11-25 n=1^{\#}$ & & $12,000 \pm 100$ & \\
\hline Italy; C. herpeticus (C. scaurus), 1994-09-19 $n=1^{\#}$ & & $290 \pm 20$ & \\
\hline Italy; C. largus, $1992-10-25 n=1^{\#}$ & & $220 \pm 13$ & \\
\hline Italy; C. largus, 1994-10-16 $n=1^{\#}$ & & $1100 \pm 20$ & \\
\hline Italy; C. lividoviolaceus, 1994-09-19 $n=1^{\#}$ & & $1700 \pm 25$ & \\
\hline Italy; C. melliolens (C. talus), 1994-10-14 n $=1^{\#}$ & & $180 \pm 10$ & \\
\hline Italy; C. orellanus, $1994-10-25 n=1^{\#}$ & & $26,000 \pm 180$ & \\
\hline Italy; C. phoeniceus (C. purpureus), 1994-09-19 n $=1^{\#}$ & & $2700 \pm 28$ & \\
\hline Italy; C. praestans, $1993-09-24 \mathrm{n}=1^{\#}$ & & $130 \pm 9$ & \\
\hline Italy; C. purpurascens, $1994-09-19 \mathrm{n}=1^{\#}$ & & $220 \pm 12$ & \\
\hline Italy; C. rapaceus, $1994-10-15 n=1^{\#}$ & & $31,000 \pm 200$ & \\
\hline Italy; C. rufo-olivaceus, 1994-09-19 $n=1^{\#}$ & & $2400 \pm 23$ & \\
\hline Italy; C. sebaceus, 1994-09-19 $n=1^{\#}$ & & $380 \pm 19$ & \\
\hline Italy; C. subannulatus, 1994-10-01 $n=1^{\#}$ & & $18,000 \pm 130$ & \\
\hline Italy; C. torvus, $1994-10-08 n=1^{\#}$ & & $5600 \pm 50$ & \\
\hline Italy; C. variecolor, 1994-09-19 $n=1^{\#}$ & & $320 \pm 17$ & \\
\hline Italy; C. venetus, $1994-10-14 n=1^{\#}$ & & $5600 \pm 44$ & \\
\hline Poland; C. caerulescens, Pomlewo, $2013 n=3^{\# \#}$ & & $18 \pm 4^{* *}$ & \\
\hline Poland; C. caerulescens, Pomlewo, $2015 n=25^{\# \#}$ & $5.8 \pm 1.0$ & & $5.1 \pm 1.0$ \\
\hline Poland; C. caperatus, TLP, $1996 n=20^{\# \#}$ & $13,000 \pm 110$ & & $4200 \pm 45$ \\
\hline Poland; C. caperatus, WLP, $1998 n=15^{\# \#}$ & $16,000 \pm 180$ & & $5300 \pm 65$ \\
\hline Poland; C. caperatus, Darżlubska Wilderness, $2001 n=15^{\# \#}$ & $6500 \pm 60$ & & $2000 \pm 19$ \\
\hline Poland; C. caperatus, Przymuszewo, $2002 n=16^{\# \#}$ & $12,000 \pm 94$ & & $5400 \pm 43$ \\
\hline Poland; $C$. caperatus, Darżlubska Wilderness, $2003 n=15^{\# \#}$ & $5100 \pm 43$ & & $2100 \pm 19$ \\
\hline Poland; $C$. caperatus, Słupsk county, Kępice, $2003 n=31^{\# \#}$ & $5200 \pm 49$ & & $2000 \pm 19$ \\
\hline Poland; C. caperatus, Sulęczyno, $2006 n=70^{\# \#}$ & $5200 \pm 50$ & & $3500 \pm 25$ \\
\hline Poland; C. caperatus, Strzebielino, $2006 n=16^{\# \#}$ & $4600 \pm 42$ & & $1800 \pm 23$ \\
\hline Poland; C. caperatus, Tuchola Pinewoods, Lubichowo, $2007 n=53^{\# \#}$ & $7300 \pm 58$ & & $2900 \pm 24$ \\
\hline Poland; C. caperatus, Gołubie, $2008 n=15^{\# \#}$ & $6500 \pm 47$ & & $3000 \pm 22$ \\
\hline Poland; C. caperatus, Tuchola Pinewoods, Lubichowo, $2010 n=16^{\# \#}$ & $5600 \pm 58$ & & $1900 \pm 24$ \\
\hline Poland; C. olivaceofuscus Pomlewo, $2013 n=14^{\# \#}$ & & $10 \pm 2$ & \\
\hline Poland; C. olivaceofuscus Pomlewo, $2015 n=54^{\# \#}$ & $9.2 \pm 2.0$ & & $6.9 \pm 1.6$ \\
\hline Poland; C. trivialis, Pomlewo, $2015 n=35^{\# \#}$ & & $93 \pm 2$ & \\
\hline
\end{tabular}

Notes: " Number of individual samples; ${ }^{\# \#}$ Number of individuals in a pool; TLP (Trójmiejski Landscape Park); WLP (Wdzydze Landscape Park);

${ }^{*}$ Mean \pm S.D. (range) and median value; ${ }^{* *}$ Measurement uncertainty 
samples), and from the Pomerania region, 16 composite samples were examined, which were prepared using from 3 to 70 individuals per location (Table 1). The activity concentrations of ${ }^{134} \mathrm{Cs}$ and ${ }^{137} \mathrm{Cs}$ in samples collected in Italy and Poland were determined using a validated method of gamma spectrometry with coaxial high purity germanium (HPGe) detectors.

Details on the gamma spectrometer calibration, detector parameters, and quality assurance of the measurements and instrument used in Italy [HPGe high purity detectors (P-type HPGe and HPGe-N-EG G ORTEC, relative efficiencies between 25 and $80 \%$ and resolution of approximately $2.0 \mathrm{keV}$ (FWHM) at 1:33 MeV energy), shielded by lead walls (thickness about $10 \mathrm{~cm}$ ), calibrated with multirange source QCY 48 (energy range between $59 \mathrm{keV}$ and $1.836 \mathrm{MeV}$ ) and equipped with spectra processing program (GammaVision 7:02ORTEC)] were provided in a paper by Consiglio et al. (1990). For instrument used in Poland, the germanium detector relative efficiency was $18 \%$ and a resolution of $1.9 \mathrm{keV}$ at $1.332 \mathrm{MeV}$ (with associated electronics). The equipment was calibrated using a multi-isotope standard and the method was fully validated. The reference solution, "Standard solution of gamma emitting isotopes, code BW/Z-62/27/07" produced at the IBJ-Świerk near/Otwock in Poland, was used for preparing reference samples for equipment calibration. The same geometry of cylindrical dishes with $40 \mathrm{~mm}$ diameter (as applied for environmental samples) was used for reference samples during equipment calibration. The laboratory involved was subject to routine checks to ensure high standards of analytical quality and analytical control and participated successfully in the inter-comparison exercises organized by IAEA-MEL Monaco (IAEA-414, Irish and North Sea Fish) to confirm the reliability and accuracy of the method (Falandysz et al. 2015a, b; Wang et al. 2015; Zalewska and Saniewski 2011). Repeated analysis gave values of ${ }^{137} \mathrm{Cs}$ $5.06 \pm 0.64 \mathrm{~Bq} \mathrm{~kg}^{-1} \mathrm{db}^{4}{ }^{4} \mathrm{~K}-474.5 \pm 19.3 \mathrm{~Bq} \mathrm{~kg}^{-1} \mathrm{db}$, while the estimated target value was equal to $5.18 \pm 0.10 \mathrm{~Bq} \mathrm{~kg}^{-1} \mathrm{db}$ for ${ }^{137} \mathrm{Cs}$ and $481 \pm 16 \mathrm{~Bq} \mathrm{~kg}^{-1} \mathrm{db}$ for ${ }^{4 \circ} \mathrm{K}$. In the gamma spectrometry measurements, the limit of quantification was calculated using GENIE 2000 as a Minimum Detectable Activity (MDA) defined by Curie (1968). Data were calculated for dehydrated fungal material (at $105{ }^{\circ} \mathrm{C}$ ) and corrected back to the exact date of sample collection.

\section{Results and discussion}

Table 1 presents all the mushroom names, site locality, year of collection, number of fruitbodies, and measurement data. The fruitbodies collected in the Reggio Emilia in the period from 1992 to 1994 showed relatively high activity concentrations of ${ }^{137} \mathrm{Cs}$ (half-life $\mathrm{T}_{1 / 2} 30.05$ years) at a range from $120 \mathrm{~Bq} \mathrm{~kg}{ }^{-1} \mathrm{db}$ in C. anserinus to $31,000 \mathrm{~Bq} \mathrm{~kg}^{-1} \mathrm{db}$ in
C. rapaceus, with both collected in 1994 (Table 1). If recalculated to fresh weight (assuming a moisture content of fruiting bodies at $90 \%$ ), the values would be $12 \mathrm{~Bq} \mathrm{~kg}^{-1}$ for $C$. anserinus and $3100 \mathrm{~Bq} \mathrm{~kg}^{-1}$ for C. rapaceus.

In some Cortinarius species, in Reggio Emilia, ${ }^{134} \mathrm{Cs}$ (halflife $\mathrm{T}_{1 / 2} 2.06$ years) was detected, but activity concentrations were visibly lower. They ranged from $8 \mathrm{~Bq} \mathrm{~kg}^{-1} \mathrm{db}$ in C. cotoneus to $987 \mathrm{~Bq} \mathrm{~kg}^{-1} \mathrm{db}$ in C. rapaceus, and the latter showed also the greatest ${ }^{137} \mathrm{Cs}$ activity concentration. It has been shown that there is a relationship between the activity concentration of both isotopes in mushrooms (fruiting bodies). The ratio of activity concentrations of ${ }^{134} \mathrm{Cs}$ to concentrations of ${ }^{137} \mathrm{Cs}$ referenced to 1986 varied within a narrow range from 0.29 to 0.46 . The averaged value was 0.38 . It should be noted that this value only slightly differs from that specific for the Chernobyl fallout, which was 0.54 (Aarkrog et al. 1988; Strandberg 2004). Taking into account the value specific for the Chernobyl fallout and activity concentrations of ${ }^{134} \mathrm{Cs}$ referenced to 1986 , it is possible to calculate activity concentrations of ${ }^{137} \mathrm{Cs}$ originating from the Chernobyl accident. It was calculated that this ${ }^{137} \mathrm{Cs}$ constituted about $63 \%$ of the total activity concentration of the isotope present in 1986 in fruiting bodies of examined mushrooms (the range is from 53 to $85 \%$ ). This means that as much as $32 \%$ of ${ }^{137} \mathrm{Cs}$ in mushrooms were from the global fallout from nuclear bomb testing.

The species $C$. anserinus, $C$. auroturbinatus, C. scaurus (herpeticus), C. largus (one sample), C. (talus) melliolens, C. praestans, C. purpurascens, C. sebaceus, and C. variecolor did not show ${ }^{134} \mathrm{Cs}$ at a level $>0.1 \mathrm{~Bq} \mathrm{~kg}^{-1} \mathrm{db}$, while activity levels of ${ }^{137} \mathrm{Cs}$ were $<300 \mathrm{~Bq} \mathrm{~kg}^{-1} \mathrm{db}$ (Table 1). C. caperatus collected in Poland did not show activity concentrations from ${ }^{134} \mathrm{Cs}$ at the time of analysis (spring 2012).

Across all the Cortinarius sporocarps examined from Reggio Emilia, the activity concentrations were relatively high in C. alboviolaceus, C. caperatus, C. duracinus, C. rapaceus, and $C$. subannulatus in which ${ }^{137} \mathrm{Cs}$ was at $10,000 \sim 100,000 \mathrm{~Bq} \mathrm{~kg}^{-1} \mathrm{db}$. Smaller activity concentrations were found in C. bivelus, C. bulliardii, C. cotoneus, C. largus, C. lividoviolaceus, C. phoeniceus (C. purpureus), C. rufoolivaceus, $C$. torvus, and $C$. venetus with levels at $1000 \sim 6000 \mathrm{~Bq} \mathrm{~kg}{ }^{-1} \mathrm{db}$, and further in $C$. anserinus, $C$. auroturbinatus, C. herpeticus (C. scaurus), C. herpeticus (C. scaurus), C. largus, C. melliolens (C. talus), C. praestans, C. purpurascens, C. sebaceus, and C. variecolor with activity concentrations at $100 \sim 600 \mathrm{~Bq} \mathrm{~kg}^{-1} \mathrm{db}$ (Table 1).

Cortinarius caperatus and also Cortinarius armillatus (Fr.) Fr., highly accumulated pre- and post-Chernobyl ${ }^{137} \mathrm{Cs} .{ }^{[25-26]}$ Cortinarius fruitbodies of C. caperatus, C. armillatus, and Cortinarius traganus (Fr.) Fr., were very efficient accumulators of ${ }^{134 / 137} \mathrm{Cs}$ (median value of ${ }^{137} \mathrm{Cs}$ in individuals from Slovenia was respectively at 22,000, 44,000, and $12,000 \mathrm{~Bq} \mathrm{~kg}^{-1} \mathrm{db}$ ), while C. praestans was a weak 
accumulator, as indicated by our results and a study by Byrne (1998). Our results for C. caperatus as efficient accumulators of ${ }^{137} \mathrm{Cs}$ agreed with data by Strandberg (1994 and 2004), while that for $C$. armillatus this is new record. The largest amount of data on ${ }^{137} \mathrm{Cs}$ in this study concerns C. caperatus, both from the Reggio Emilia in Italy and Pomerania in Poland (Table 1). This species accumulates ${ }^{137} \mathrm{Cs}$ much more efficiently in caps than in stipes and the range of the values of ${ }^{137} \mathrm{Cs}$ cap to stipe activity concentration quotient $\left(\mathrm{Q}_{\mathrm{C} / \mathrm{S}}\right)$ for the fruitbodies collected in Pomerania was from 1.4 to 3.1.

The highest activity concentration of ${ }^{137} \mathrm{Cs}$ $\left(16,000 \mathrm{~Bq} \mathrm{~kg}{ }^{-1} \mathrm{db}\right)$ in caps of C. caperatus from northern Poland was identified in a sample gathered in 1998. High activity concentrations were also found in individuals collected in 1996 $\left(13,000 \mathrm{~Bq} \mathrm{~kg}^{-1} \mathrm{db}\right)$ and in $2002\left(12,000 \mathrm{~Bq} \mathrm{~kg}^{-1} \mathrm{db}\right)$. The activity concentrations of ${ }^{137} \mathrm{Cs}$ in most samples collected in the period from 2001 until 2010 remained in the range from 3800 to $9000 \mathrm{~Bq} \mathrm{~kg}^{-1} \mathrm{db}$. Regarding the northern Polish region, the lowest ${ }^{137} \mathrm{Cs}$ activity concentrations were determined for other species of the genus Cortinarius that were collected in 2013 and 2015. In 2013, ${ }^{137} \mathrm{Cs}$ in fruiting bodies of C. olivaceofuscus was at $11 \mathrm{~Bq} \mathrm{~kg}{ }^{-1} \mathrm{db}$ and in C. caerulescens at $18 \mathrm{~Bq} \mathrm{~kg}^{-1} \mathrm{db}$. In 2015 , the activity concentration in $C$. trivialis was at $93 \mathrm{~Bq} \mathrm{~kg}^{-1} \mathrm{db}$, while the caps and stipes of C. caerulescens and $C$. trivialis were at a level of a few $\mathrm{Bq} \mathrm{kg}^{-1} \mathrm{db}$ (Table 1).

There were some similarities in the ${ }^{137} \mathrm{Cs}$ activity concentrations in C. caperatus collected in the Reggio Emilia in 1995 and 1999 (at 14,000 and $17,000 \mathrm{~Bq} \mathrm{~kg}{ }^{-1} \mathrm{db}$ or 1400 and $1700 \mathrm{~Bq} \mathrm{~kg}^{-1}$ fresh weight base, respectively) and fruitbodies collected in 1996-1998 in Pomerania (in caps at 13,000$16,000 \mathrm{~Bq} \mathrm{~kg}^{-1} \mathrm{db}$ or $1300-1600 \mathrm{~Bq} \mathrm{~kg}^{-1}$ fresh weight base) (Table 1). The fruitbodies of C. caperatus sampled in Denmark in 1994 contained ${ }^{137} \mathrm{Cs}$ at $13,000 \mathrm{~Bq} \mathrm{~kg}^{-1} \mathrm{db}$, while individuals from a montane region of Norway sampled in 1994 contained ${ }^{137} \mathrm{Cs}$ at $7700 \mathrm{~Bq} \mathrm{~kg}^{-1} \mathrm{db}$ (median value) (Strandberg 1994 and 2004).

Recently, coral fungi of the genus Clavaria were reported as efficient accumulators of radiocaesium and samples collected in Japan after the Fukushima nuclear accident showed radiocaesium at $28,000 \mathrm{~Bq} \mathrm{~kg}^{-1}$ fresh weight base (Merz et al. 2015).

\section{Conclusion}

The greatest activity concentrations of ${ }^{137} \mathrm{Cs}$ in mushrooms of the genus Cortinarius collected both in the Reggio Emilia in Italy and in the region of northern Poland were found in C. caperatus, which is one of the most popular species from this genus, and it's very high capacity for radiocaesium accumulation was confirmed. Besides ${ }^{137} \mathrm{Cs}$, the isotope ${ }^{134} \mathrm{Cs}$ was detected in some species from Italy. An average calculated ratio of activities of ${ }^{134} \mathrm{Cs}$ to ${ }^{137} \mathrm{Cs}$ referenced to 1986 was equal to 0.38 in mushrooms from the Reggio Emilia, and this value slightly differs from that specific for the Chernobyl fallout, which was 0.54 . It was calculated that ${ }^{137} \mathrm{Cs}$ originating from the Chernobyl accident constituted about $68 \%$ of the total activity concentration of the isotope in Reggio Emilia in 1986, while as much as $32 \%$ of ${ }^{137} \mathrm{Cs}$ in mushrooms resulted from the global fallout from nuclear bomb testing.

Open Access This article is distributed under the terms of the Creative Commons Attribution 4.0 International License (http:// creativecommons.org/licenses/by/4.0/), which permits unrestricted use, distribution, and reproduction in any medium, provided you give appropriate credit to the original author(s) and the source, provide a link to the Creative Commons license, and indicate if changes were made.

\section{References}

Aarkrog A. Bøtter-Jensen L, Qing Jiang C, Dahlgaard H, Hansen H, Holm E, Lauridsen B, Nielsen SP, Søegaard-Hansen J (1988) Environmental Radioactivity in Denmark in 1986. Risø Report 1988. RISØ-R-549

Bakken LR, Olsen RA (1990) Accumulation of radiocaesium in fungi. Can. J Microbiol 36:70-710

Baldini E, Nyatemu K (1990) Tubertini, O. ${ }^{137} \mathrm{Cs} /{ }^{134} \mathrm{Cs}$ anomalous ratios in organic soils and mushrooms affected by Chernobyl pollution. Radiochim Acta 49:49-51

Bem H, Lasota W, Kuśmierek E, Witusik M (1990) Accumulation of 137Cs by mushrooms from Rogożno area of Poland over the period 1984-1988. J Radioanal Nucl Chem Lett 145:39-46

Bulko NI, Shabaleva M, Kozlov AK, Tolkacheva NV, Mashkov LA (2014) The ${ }^{137}$ Cs accumulation by forest-derived products in the Gomel region. J Environ Radioact 127:150-154

Byrne AR (1998) Radioactivity in fungi in Slovenia, Yugoslavia, following the Chernobyl accident. J Environ Radioac 6:177-183

Cocchi L, Vescovi L, Petrini L, Petrini O (2006) Heavy metals in edible mushrooms in Italy. Food Chem 98:277-284

Consiglio G, Gattavecchia E, Tonelli D, Cocchi L (1990) La radioattività nei funghi: attualità del problema ed opportunità di un approfondimento. Riv Micol 33:227-231

Curie LA (1968) Limits for qualitative detection and quantitative determination. Application to radiochemistry. Anal Chem 40:586-593

De Cort M, Dubois G, Fridman SD, Germenchuk MG, Izrael YA, Janssens A, Jones AR, Kelly GN, Kvasnikova EV, Matvenko II, Nazarov IM, Pokumeiko YM, Sitak VA, Stukin ED, Tabuchny LY, Tsaturov YS, Avdyushin SI (1998) Atlas of caesium deposition on Europe after the Chernobyl accident. Luxembourg: Office for Official Publications of the European. Communities 92:828-3140

Eckl P, Hofmann W, Turk R (1985) Uptake of natural and man-made radionuclides by lichens and mushrooms. Radiat Environ Biophys 25:43-54

Falandysz J (2014) Distribution of mercury in gypsy Cortinarius caperatus mushrooms from several populations: an efficient accumulator species and estimated intake of element. Ecotox Environ Saf 110:68-72

Falandysz J, Borovička J (2013) Macro and trace mineral constituents and radionuclides in mushrooms - health benefits and risks. Appl Microbiol Biotechnol 97:477-501

Falandysz J, Kunito T, Kubota R, Bielawski L, Mazur A, Falandysz JJ, Tanabe S (2007a) Selected elements in Brown birch Scaber stalk Leccinum scabrum. J Environ Sci Health Part A 42:1615-1623 
Falandysz J, Kunito T, Kubota R, Lipka K, Mazur A, Falandysz JJ, Tanabe S (2007b) Selected elements in fly agaric Amanita muscaria. J Environ Sci Health Part A 42:1615-1623

Falandysz J, Kunito T, Kubota R, Gucia M, Mazur A, Falandysz JJ, Tanabe S (2008) Some mineral constituents of parasol mushroom Macrolepiota procera. J Environ Sci Health Part B 43:187-192

Falandysz J, Zalewska T, Krasińska G, Apanel A, Wang Y, Pankavec S (2015a) Evaluation of the radioactive contamination in fungi genus Boletus in the region of Europe and Yunnan Province in China. Appl Microbiol Biotechnol 99:8217-8224

Falandysz J, Zhang J, Zalewska T, Apanel A, Wang Y, Wiejak A (2015b) Distribution and possible dietary intake of radioactive ${ }^{137} \mathrm{Cs},{ }^{4 \circ} \mathrm{K}$ and ${ }^{226} \mathrm{Ra}$ with the pantropical mushroom Macrocybe gigantea in SW China. J Environ Sci Health Part A 50:941-945

Index Fungorum (2015) http://www.indexfungorum. org/names/Names.asp (accessed on November 12, 2015)

García MA, Alonso J, Melgar MJ (2015) Radiocaesium activity concentrations in macrofungi from Galicia (NW Spain): influence of environmental and genetic factors. Ecotox Environ Saf 115:152-158

Grodzinskaya AA, Berreck M, Haselwandter K, Wasser SP (2003) Radiocesium contamination of wild-growing medicinal mushrooms in Ukraine. Int J Med Mush 5:61-86

Grodzinskaya AA, Syrchin SA, Kuchma ND, Wasser SP (2013) Macromycetes accumulative activity in radionuclide contamination conditions of the Ukraine territory. Part 6. - P.217260, 368-373. In: Mycobiota of Ukrainian Polesie: Consequences of the Chernobyl disaster. Kiev: Naukova dumka (In Russian)

Grueter H (1964) Eine selektive Anreicherung des Spaltprodukts ${ }^{137} \mathrm{Cs}$ in Pilzen. Naturwissenachaften 51:161-162

Haselwandter K, Berreck M, Brunner P (1988) Fungi as bioindicators of radiocaesium contamination: pre- and post-Chernobyl activities. Trans Br Mycol Soc 90:711-174

Kirchner G, Daillant O (1998) Accumulation of 210Pb, 226Ra and radioactive cesium by fungi. Sci Total Environ 222:63-70

Kotłów J, Chudzińska M, Barałkiewicz D, Falandysz J (2015) Badania nad składem i współzależnościami występowania wybranych pierwiastków śladowych w grzybie Sarcodon imbricatus. XI Międzynarodowa Konferencja NaukowoTechniczna. „Obieg pierwiastków w przyrodzie bioakumulacja - toksyczność - przeciwdziałanie”. 10 września
2015 r. Warszawa. IOŚ - PIB; Instytut Ochrony Środowiska Państwowy Instytut Badawczy. Streszczenia posterów, 64

Merz S, Shozugawa K, Steinhauser G (2015) Analysis of Japanese radionuclide monitoring data of food before and after the Fukushima nuclear accident. Environ Sci Technol 49:2875-2885

Mietelski JW, Dubchak S, Błażej S, Anielska T, Turnau K (2010) ${ }^{137} \mathrm{Cs}$ and ${ }^{4 \circ} \mathrm{K}$ in fruiting bodies of different fungal species collected in a single forest in southern Poland. J Environ Radioact 101:706-711

Saniewski M, Zalewska T, Krasińska G, Szylke N, Wang Y, Falandysz J (2016) ${ }^{90} \mathrm{Sr}$ in king bolete Boletus edulis and certain other mushrooms consumed in Europe and China. Sci Total Environ 543:287294

Steinhauser G (2014) Fukushima's forgotten radionuclides: a review of the understudied radioactive emissions. Environ Sci Technol 48: 4649-4663

Steinhauser G, Merz S, Hainz D, Sterba JH (2013) Artificial radioactivity in environmental media (air, rainwater, soil, vegetation) in Austria after the Fukushima nuclear accident. Environ Sci Pollut Res 20: 2527-2434

Steinhauser G, Brandl A, Johnson TE (2014) Comparison of the Chernobyl and Fukushima nuclear accidents: a review of the environmental impacts. Sci Total Environ 470-471:800-817

Strandberg M (1994) Radiocesium in a Danish pine forest ecosystem. Sci Total Environ 157:125-132

Strandberg M (2004) Long-term trends in the uptake of radiocesium in Rozites caperatus. Sci Total Environ 327:315-321

Wang Y, Zalewska T, Apanel A, Zhang J, Wiejak A, Falandysz J (2015) ${ }^{137} \mathrm{Cs},{ }^{134} \mathrm{Cs}$ and natural ${ }^{4 \circ} \mathrm{K}$ in sclerotia of Wolfiporia extensa fungus collected across of the Yunnan land in China. J Environ Sci Health Part B 50:654-658

Yoshida S, Muramatsu Y, Steiner M, Belli M, Pasquale A, Rafferty B, Rühm W, Rantavaara A, Linkov I, Dvornik A, Zhuchenko T (2000) In Relationship between radiocesium and stable cesium in plants and mushrooms collected from forest ecosystems with different contamination levels. Proceedings of the 10th International Congress of the International Radiation Protection Association, May, 2000; Hiroshima P-11-244

Zalewska T, Saniewski M (2011) Bioaccumulation of gamma emitting radionuclides in red algae from the Baltic Sea under laboratory conditions. Oceanologia 53:631-650 